\title{
"A Constant State of Learning"
}

\section{WITH THE RIGHT APPROACH, BOTH SIDES CAN BENEFIT FROM MENTORING RELATIONSHIPS}

\section{By Rhea Wessel}

In mid-2015, Lars van de Loo, CFA, jumped at the chance to participate in a newly formed mentoring program offered by CFA Society Netherlands. He had just returned from a four-month sabbatical from his job as a strategy analyst at a clearing bank in Amsterdam and wanted to consider his next career steps.

"I thought it would be interesting for me to reflect on my career and my challenges with someone outside of my company," he says. "I wanted to get a different view from someone who had a different experience, [who lived] in different geographies. I was very enthusiastic."

Veteran mentors, executive coaches, and other experts agree that mentoring can benefit whole firms and individual careers.

Establishing a culture of mentoring within an organization can promote a culture of continual learning.

Seeking and preparing for a mentoring relationship should be researched as thoroughly as a potential investment.

According to a recent CFA Institute Financial NewsBrief poll, nearly $65 \%$ of respondents have mentored fellow finance professionals. Van de Loo was one of a dozen mentors and mentees in the CFA Society Netherlands program (launched in 2015), and the experience gave him a boost of confidence. "My mentor that you cannot ever know everything and you shouldn't strive to know everything," challenged me on the fact he says. "This helped me become more assertive in my career."

Eighteen more mentors and mentees were selectively matched this year, according to Joost Caljé, CFA, careers chair at CFA Society Netherlands.

It was Caljé, a director at Amsterdam financial services consultancy Lucas Pearce Consulting, who launched and oversaw the mentoring program. The program was created after a membership survey showed that local charterholders wanted greater recognition for the CFA charter and help boosting their careers.

"My intention was for the program to be lightly scripted," Caljé says. "For instance, you can get mentored for any goal, not just professional goals. The only thing we asked was that people consider the time commitment. During nine months of mentoring, we recommended that every quarter, people should meet once, and every month people should touch base."

But are infrequent meetings enough for mentoring to be effective? And how do you know a mentor-mentee relationship will be effective and rewarding?

\section{A SPIRIT OF LEARNING}

Chip Bell, author of Managers as Mentors: Building Partnerships for Learning, says learning should be the primary goal of a mentor-mentee relationship. Such an attitude helps companies and organizations be more competitive overall.

The problem, according to Bell, is that companies cannot afford to put their employees in training courses over and over again. But establishing a culture of mentoring within an organization can go a long way toward the same goal. "A mentoring program helps organizations stay in a constant state of learning, which is where they need to be if they want to be innovative," he says.

At the same time, an organization won't succeed in cultivating a learning culture if competition is fierce within the company and people are shamed for asking what might seem like dumb questions.

Bell says investment managers in particular must be careful how they come across to a mentee. "It's great when you need an expert, but it can also lead to an arrogant style. This is just the opposite of what you need to be a good mentor. A good mentor has humility, openness, vulnerability, all those things. That authenticity and realness is essential to being a great mentor."

Now a veteran of the finance industry, Bell recalls an early experience he had with a boss who was mentoring him when he worked at a large bank. Bell, when asked to hire someone, found a candidate who, though he had a fine Ivy League resume and was top of his class, had certain traits that were possibly incompatible with the existing team. Bell hired the candidate despite some reservations.

"When the new hire didn't work out, my boss never once said, 'I told you so.' He simply said, 'Let's talk about what you learned.' He took time to do a post-mortem on the decision I made," says Bell. The boss succeeded in teaching a lesson without humiliating Bell.

\section{UNDERSTANDING ROLES}

Like Bell, Camille Preston, founder and CEO of AIM Leadership, based in Cambridge, MA, recommends that you begin mentoring relationships by considering what you can learn from the other person. "Everyone around you can teach you something," she says. But you've also got to make it easy for your mentor to help you.

If you are the mentee, you need to work your appointments around the mentor's schedule and not the other way around. And you need to make sure your mentor finds the experience of advising you rewarding rather than frustrating.

This may mean forgoing an agenda or a highly structured relationship when working with a mentor. Mentees 
may just need to allow the conversation to unfold. "Because people are hesitant to develop authentic relationships, many mentoring programs try to create a structure for the relationship that can actually lessen its impact," Preston says.

Nowadays, many people hire career coaches when they're looking for advice, but Preston says a coach is different from a mentor. Keeping the differences in mind can make life easier for a mentor.

According to Preston, mentoring is "follow me, this is what works for me," while coaching is serving as a co-pilot. In a coaching relationship, the coach says, "I'm going to help you navigate from where you are to where you want to go." And both of these things are different from the process of receiving feedback, which can be as fast and easy as asking, "What do you think about this?" But remember to listen to the other person's opinion.

That said, a mentee shouldn't be surprised if the roles reverse at some point in the relationship. Preston mentors a woman who is 10 years her junior, but lately this mentee has been helping Preston. "Build the mindset to notice people's strengths and then learn to ask people for help," says Preston. "People want to help. But it's hard to ask for help."

\section{RESEARCH MATTERS}

Preparing for interaction with a mentor is another essential task, one that should be researched as thoroughly as is done for a company or hiring manager prior to a job interview.

Amy Zhang, a managing member of Affinity Fund Services, a hedge fund administration firm in San Francisco, has multiple mentors from different industries, each about 10 years older than she is. When meeting her mentors for the first time, she makes sure she has done research on the person, their field, and possible common areas of interest.

"It's really up to the mentee to take the initiative. You can only help people who want to be helped," says Zhang. She puts an emphasis on having mentors from different

fields. Her mentors include the owner of a hedge fund marketing company, a controller at a venture capital firm, an attorney, and the owner of a medical device company.

Zhang, a former co-chair of a career committee at CFA Society San Francisco, says she finds it challenging to keep the relationship going if the mentees are not taking the initiative. "It's like a one-way conversation."

\section{CONFIDENCE BOOSTERS}

Back in Amsterdam, van de Loo intuitively knew that his relationship with his mentor would be a two-way street.

He was assigned to Pieter van Putten, CFA, who is the advocacy chair of CFA Society Netherlands. The two enjoyed talking about van Putten's experiences living and working in Germany and the Asia-Pacific region. After a long career in asset management, van Putten now runs his own consultancy firm focused on asset management operations, product development, business development, and strategy.

"Pieter told me he was humbled by the fact that I was willing to share about challenges on an emotional level," says van de Loo.

Van de Loo says that van Putten helped him see that he was standing in his own way regarding his career. "I was holding myself back. I thought I didn't have sufficient knowledge. I was focused on what I didn't know instead of what I do know," says van de Loo. Now he thanks van Putten for helping him come to this insight about himself.

Van Putten's advice to other charterholders who are mentors is to continue to participate. For those who are not yet mentors, he says, "As a mentor, you are also able to take something home from the process. Just do it; you will not regret it."

\section{KEEP GOING}

"Mentoring to Build a Better Profession," Enterprising Investor [www.blogs.cfainstitute.org]

Request the business plan for the CFA Society Netherlands mentoring program: sarah.belenkin@ecfainstitute.org
Van Putten adds, "Remember when you could have used some mentoring 10,15 , or 20 years ago."

Rhea Wessel is an American journalist, author, and speechwriter based near Frankfurt, Germany.

\section{Diving Boards}

\section{CAN CFA CHARTERHOLDERS MAKE A SPLASH ON CORPORATE BOARDS?}

\section{By Rhea Wessel}

Around the world, company boards of directors are under pressure from shareholders, regulators, and the media to generate results, but staffing a board with the right people and the right skills is far from an easy job. Often, search firms have trouble finding candidates with deep financial analysis skills. But does that mean charterholders have an advantage over others starting out?

Experts say the answer is a resounding maybe.
For board positions, a CFA charter is essentially a stepping stone, according to Roy Cohen, a New York-based career coach and author of The Wall Street Professional's Survival Guide. "It's what you have done with the CFA charter that makes you exciting to an organization as a potential board candidate," Cohen says.

In other words, charterholders who aspire to board positions in the long term have a solid basis in sought-after 